\title{
Performance of Shear Reinforcement against Punching Shear Loads
}

\author{
Ahmed M. Issa, Mohamed M. Salem, Mohamed T. Mostafa, Hamed M. Hadhoud, Hatem H. Ghith
}

\begin{abstract}
This research targets to maximize the ductility and strength of the reinforced concrete flat slabs. However, to be efficient, the shear reinforcement must be anchored well in the tension and compression zones of the slab. The test results on the slab-column connection models which provided with shear reinforcement are introduced in this study. The benefits of using shear reinforcement are to reduce the slab thickness, and to minimize both the cost and the total weight of the structure. Twelve flat slab specimens have been tested to study the effect of different types of steel RFT on the punching shear of the flat slab. The experimental parameters include no shear reinforcement which study the advantage of using tension RFT ONLY against punching shear, no shear reinforcement which study the advantage of using compression RFT against punching shear, shear RFT (Vertical Stirrups) which study the effect of using shear RFT with constant distribution $0.5 d$, and a new distribution of shear stirrups which study the effect of using new different width \& spacing of vertical stirrups. The twelve specimens were loaded with concentrated load at the mid span until failure. The general behavior of the deformation of the tested slab specimens was examined and recorded (cracking, deflection, and strain in both steel and concrete). A comparison established between the experimental and the numericaltheoretical results obtained from applying the punching shear strength formula given in design codes, and finite element modeling analysis; ABAQUS 2017 software package was used for this analysis. A total of six building codes were examined with regard to their provisions concerning the punching shear. A comparison had been made between the research test results and the codes equations to improve the methods of the analysis about the flat slabs. This study aimed to improve the punching shear capacity of flat slab which leads to more accurate results compared with the codes predictions. To achieve this aim, an experimental and numerical study was carried out for this investigation.
\end{abstract}

Keywords: Flat Plates; Punching Shear; Slab-Column Connection; Shear Reinforcement; Vertical Closed Stirrups.

\section{INTRODUCTION}

The most economical system in reinforced concrete structures is the flat slab. It provides flexibility in the architectural design; which maximize the clear space, minimize the building height, and minimize the construction time. However,

Revised Manuscript Received on December 30, 2019.

* Correspondence Author

Ahmed M. Issa *, lecturer Assistant, Housing \& Building National Research Center, HBRC, Giza, Egypt. Email: engahmed3essa@gmail.com

Mohamed M. Salem, Associate Professor, Housing \& Building National Research Center, HBRC, Giza, Egypt. Email: mm.aladawy@gmail.com

Mohamed T. Mostafa, professor, Cairo University, Giza, Egypt. Email: talatmostafa@gmail.com

Hamed M. Hadhoud, professor, Cairo University, Giza, Egypt. Email: hamedhadhoud@yahoo.com

Hatem H. Ghith, professor, Housing \& Building National Research Center, HBRC, Giza, Egypt. Email: hatem_ghith@hotmail.com

(c) The Authors. Published by Blue Eyes Intelligence Engineering and Sciences Publication (BEIESP). This is an open access article under the CC BY-NC-ND license (http://creativecommons.org/licenses/by-nc-nd/4.0/) the punching failure due to the unbalanced shear and moment transfer in column slab connection is considered a critical problem in flat slab system. The unbalanced moment is transferred by the combination of flexure, shear, and torsion in the slab next to column faces. When shear stresses due to shear forces and moment transfer in the region of flat slab next to column become too high, a punching failure will occur. Since many years ago, punching has been a problem to engineers who tried to fully understand it. It does not matter how many experiments, analysis, and models were made which relied on empiric results that did not describe the totally phenomenon. The test parameters which used are the reinforcement properties, the geometry of the slabs, aggregate size, and loading modes. Although all of these were planned in an intelligent way, providing a huge range of results, it is impossible to cover all parameters. However, this system has a lot of problems which is the failure of the slab's punching due to the stresses concentration around column slab connections. This failure type is critical due to its brittle nature. At the time, the failure of the shear punching occurred; the strength of the structure is typically minimized due to the disconnection between column and slab therefor joint connection failure will occurs. In the structural analysis of flat slabs, the punching shear strength has a noticeable effect on the slab design parameters including slab thickness, the supporting column dimensions, flexural steel, and shear reinforcement. It was the start of using flat slabs at the beginning of 20th century, which directly supported by columns led to several researches to be started on the punching strength of flat slab. At first, research mainly covered flat slabs without punching shear reinforcement, followed by researches on flat slabs with punching shear reinforcement. Depending on the beam design, bent-up bars were the first shear reinforcement which used [1]. After that, new designing systems have been developed such as shear studs and several stirrup systems. The punching shear reinforcement system changing was always depended on researches about this subject resulting in developing of new techniques of various shear reinforcement systems

There are different types of punching failures had been recognized in flat slab of slab-column design systems; First failure called "beam-type" or "one-way" punching failure, as shown in "Fig.1.a" that known as inclined crack widening toward the total slab width. Second failure called "punching" or "two-way" shear failure which takes control in the designing of flat slab generally, as shown in "Fig.1.b" which known as pyramid-shape surface or truncated cone round the column. While the ordinary reinforced slabs, the inclination angle of pyramid surface against the failure plane is ranges around 20 to 45 degrees (Min-Yuan Cheng) [2]. Based on a thesis research about the two-way punching shear action published by. 


\section{Performance of Shear Reinforcement against Punching Shear Loads}

ACI Committee 318 (ACI Committee 318, 1963) [3], this research informs that, the area of the critical shear section at space of $d / 2$ from the faces of the column with depth $\mathrm{d}$ is bespoken "Fig.2", while $\mathrm{d}$ is the slab depth. In "Fig.2", c1 is the dimension of the column in the direction of the RFT, which this direction is assumed in "Fig.2" where $\mathrm{c} 2$ is the dimension of the column in the other direction. These meanings are found at the ACI Section 11.11.1.2 [4], as a conclusion, the interior columns of slabcolumn systems, the punishing shear stress will be taken at a "critical section" of $\mathrm{d} / 2$ from load concentrated area. Therefore, the column of rectangular shape, the area of the critical section is bo $d=2 *[(c 1+d)+(c 2+d)] * d$, where bo is the critical shear perimeter.

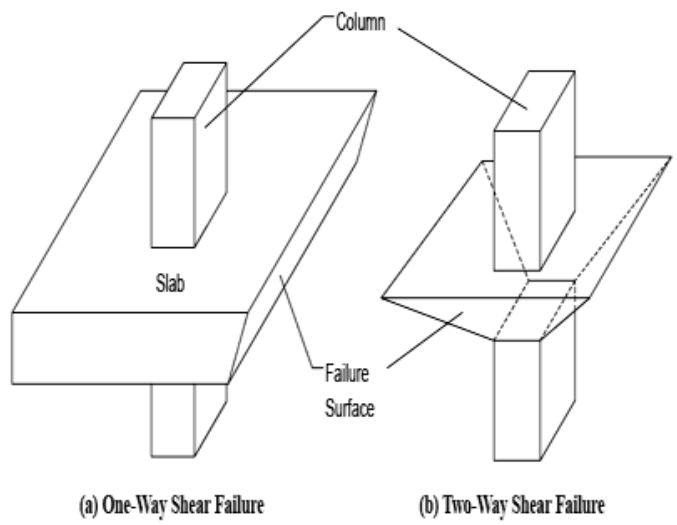

Fig. 1. Types of Shear Failure of Slabs

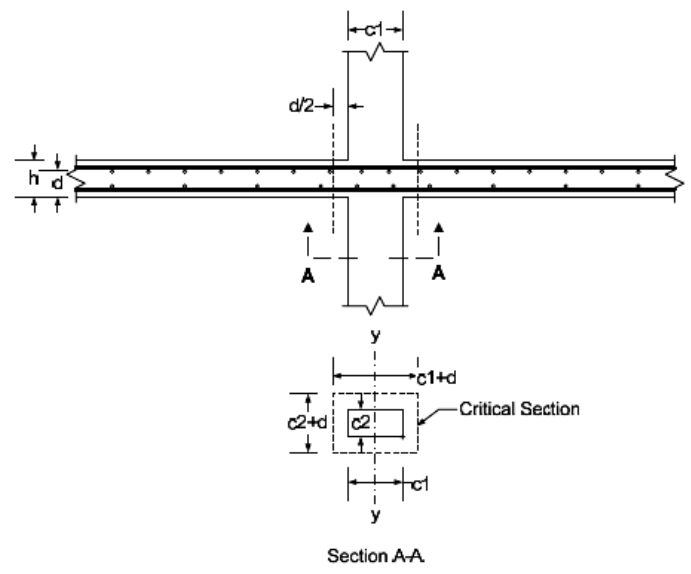

Fig. 2. Critical Shear Perimeter

There are several reinforcement techniques which used to increase the resistance of the punching shear of slabcolumn connections "Fig.3", consists of closed stirrups (Islam and Park, 1976) [5], bent-up bars (Hawkins, 1974) [5], shear studs (Dilger and Ghali, 1981) [6], and shear heads (Corley and Hawkins, 1968; 1974) [7] had been used for decades. This study of using the ideal reinforcement technique for increasing the resistance of the punching shear of slab-column connections will be discussed during this research

Previous Experimental Researches displayed that there are a little number of experimental researches have been carried on the effect flexural steel on punching shear strength of concrete flat slabs. Yamada et al. [8] performed experimental research to determine the benefits of using shear RFT type and ratio on punching shear strength of slabcolumn connection. Ramdane, K.E. [9] conducted tests on six high strength concrete slab specimen to determine the amount of flexural reinforcement and concrete compressive strength had influence on load carrying capacities of slabs. Leandro M. Trautwein and others [10] established an experimental program consisted of 11 square slab specimens with the same concrete dimensions and flexural reinforcement to determine the effect of using un-braced shear reinforcement in form of shear studs arranged in radial distribution. Carsten Siburg and Josef Hegger [11] tested 13 full scale footing specimens under uniform soil stress to investigate the punching shear response of footing with practical size. Taehun Ha et al. [12] studied the effect of slab opening on the punching shear capacity of RFT flat slab system. Based on test parameters such as the amount of RFT, the concrete strength, the dimensions of column, the openings, and the loading procedures, eight test specimens were tested in this study

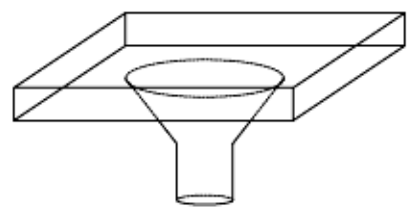

(a) Shear Capital
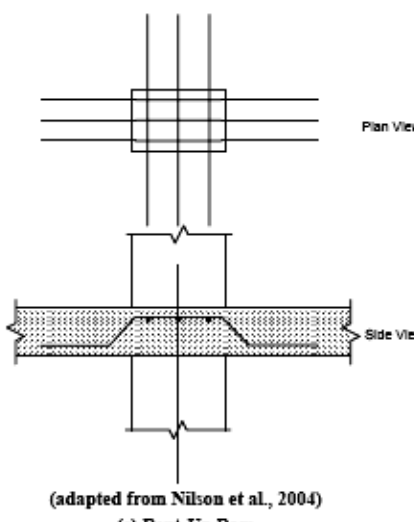

(c) Bent-Up Bars

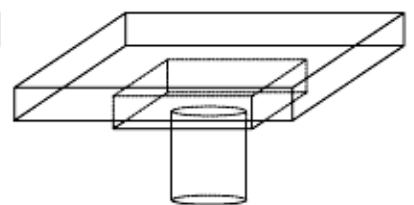

(b) Drop Panel
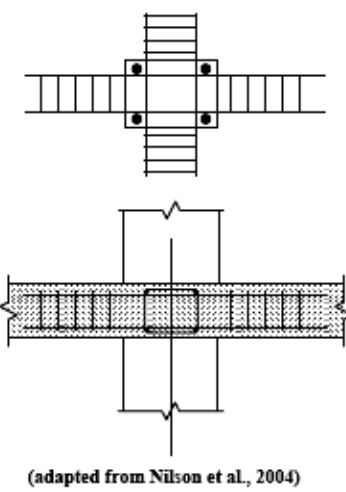

(d) Closed Stirrups
Fig. 3. Several Techniques for Increasing the Resistance of the Punching Shear in Slab - Column Connections (a, b, c \& d)

\section{EXPERIMENTAL PROGRAM}

The purpose of this experimental study is to estimate the effect of different reinforcement arrangements in tension and compression sides of specimens aiming to increase the capacity and ductility of the punching shear of flat slab system type, also to evaluate experimentally the slabcolumn connection behavior with and without punching shear reinforcement under concentric vertical load, furthermore to explore the effect of using shear reinforcement (Vertical Closed Stirrups) in enhancing the resistance of punching shear of the slab-column connections, and to know the effect of using new improvement distribution technique of shear reinforcement (Vertical Closed Stirrups).

\section{A. Details of Tested Specimens}

Present study consists of twelve specimens that identified as $S_{1}$ to $S_{12}$. Each specimen has constant slab dimensions equal $(1200 * 1200 * 120) \mathrm{mm}(\mathrm{L} * \mathrm{~B} * \mathrm{t}) \mathrm{mm}$. 
The column cross section also has constant dimensions equal $(200 * 200 * 250) \mathrm{mm}(\mathrm{L} * \mathrm{~B} * \mathrm{~h}) \mathrm{mm}$ at the center of the slab. All the details of the test specimens are listed in "Table- I", and "Fig.4" to "Fig.7".

Table- I: Specimens Details

\begin{tabular}{|c|c|c|c|c|c|}
\hline $\begin{array}{l}\text { Group } \\
\text { Name }\end{array}$ & $\begin{array}{l}\text { Specimen } \\
\text { No. }\end{array}$ & $\begin{array}{l}\text { Tension } \\
\text { RFT }\end{array}$ & $\begin{array}{c}\text { Compression } \\
\text { RFT }\end{array}$ & $\begin{array}{l}\text { Shear } \\
\text { RFT }\end{array}$ & $\begin{array}{c}\text { Distribution } \\
\text { of Shear RFT } \\
\text { (IN PLAN) }\end{array}$ \\
\hline \multirow{3}{*}{$\begin{array}{l}\text { Group } \\
\text { (A) }\end{array}$} & $\begin{array}{c}\text { S1 } \\
\text { (Control) }\end{array}$ & $10 \varnothing 10 / \mathrm{m}^{\prime}$ & \multirow{3}{*}{ Not Provided } & \multirow{3}{*}{$\begin{array}{c}\text { Not } \\
\text { Provided }\end{array}$} & \\
\hline & S2 & $10 \varnothing 12 / \mathrm{m}^{\prime}$ & & & \\
\hline & S3 & $10 \varnothing 16 / \mathrm{m}^{\prime}$ & & & \\
\hline \multirow{3}{*}{$\begin{array}{l}\text { Group } \\
\text { (B) }\end{array}$} & S4 & \multirow{3}{*}{$10 \varnothing 12 / \mathrm{m}^{\prime}$} & 10Ø8/m' & \multirow{3}{*}{$\begin{array}{c}\text { Not } \\
\text { Provided }\end{array}$} & \\
\hline & S5 & & $10 \varnothing 10 / \mathrm{m}^{\prime}$ & & --- \\
\hline & S6 & & $10 \varnothing 12 / \mathrm{m}^{\prime}$ & & \\
\hline \multirow{3}{*}{$\begin{array}{l}\text { Group } \\
\text { (C) }\end{array}$} & S7 & \multirow{3}{*}{$10 \varnothing 12 / \mathrm{m}^{\prime}$} & \multirow{3}{*}{$10 \varnothing 10 / \mathrm{m}^{\prime}$} & 4Ø8/Dir. & \multirow{3}{*}{$\begin{array}{c}\text { Stirrups Width } \\
\text { Constant } \\
(\leq 2 \mathrm{~d})\end{array}$} \\
\hline & S8 & & & 4Ø10/Dir. & \\
\hline & S9 & & & 4Ø12/Dir. & \\
\hline \multirow{3}{*}{$\begin{array}{l}\text { Group } \\
\text { (D) }\end{array}$} & S10 & \multirow{3}{*}{$10 \varnothing 12 / \mathrm{m}^{\prime}$} & \multirow{3}{*}{ 10Ø10/m' } & 4Ø8/Dir. & \multirow{3}{*}{$\begin{array}{l}\text { Stirrups Width } \\
\text { Variable }\end{array}$} \\
\hline & S11 & & & 4Ø10/Dir. & \\
\hline & S12 & & & 4Ø12/Dir. & \\
\hline
\end{tabular}

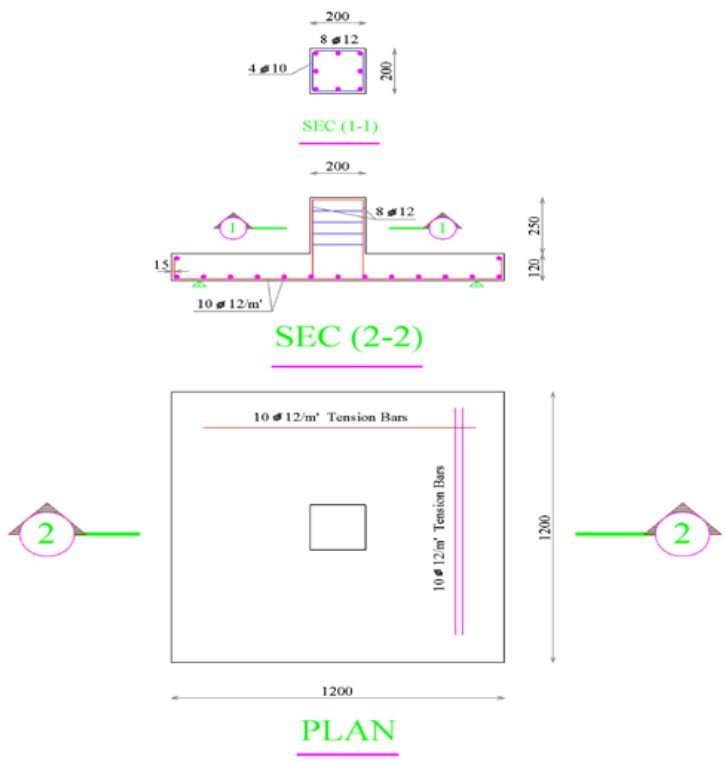

Fig. 4. Test Specimen $S_{2}$ Represent Group (A)

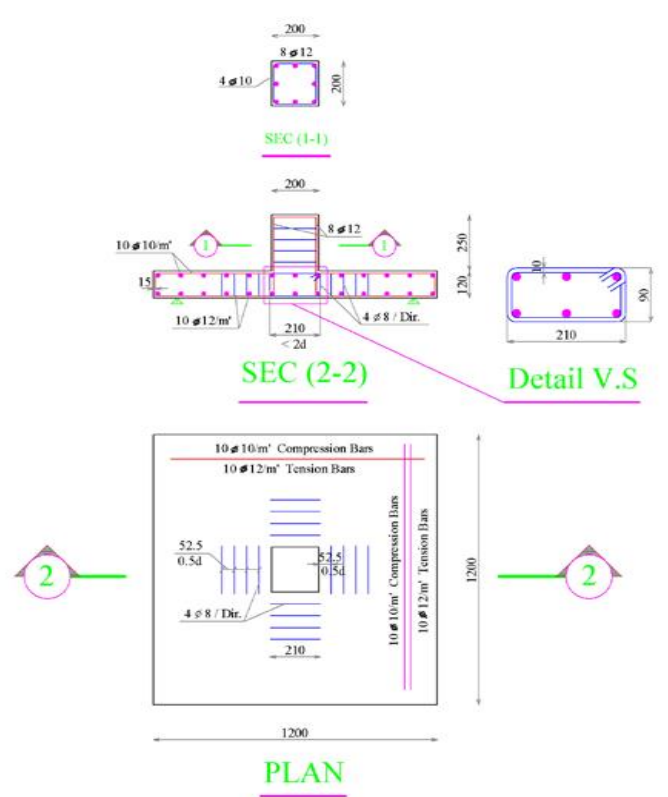

Fig. 5. Test Specimen $S_{5}$ Represent Group (B)

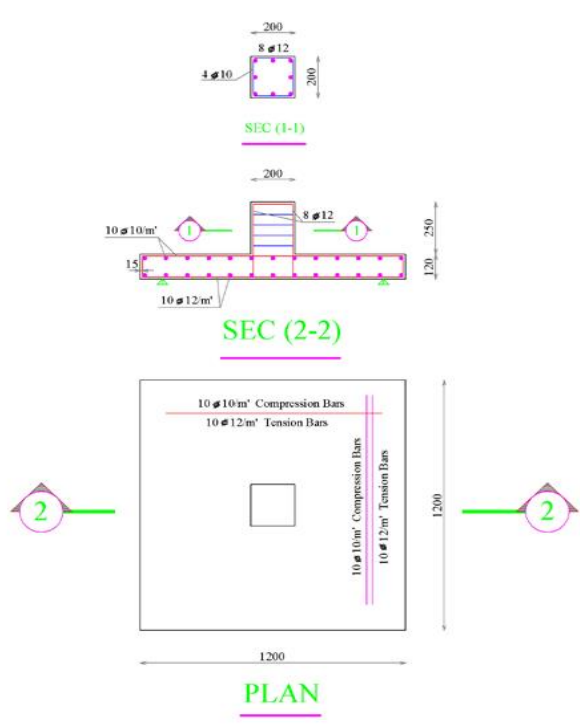

Fig. 6. Test Specimen $S_{7}$ Represent Group (C)

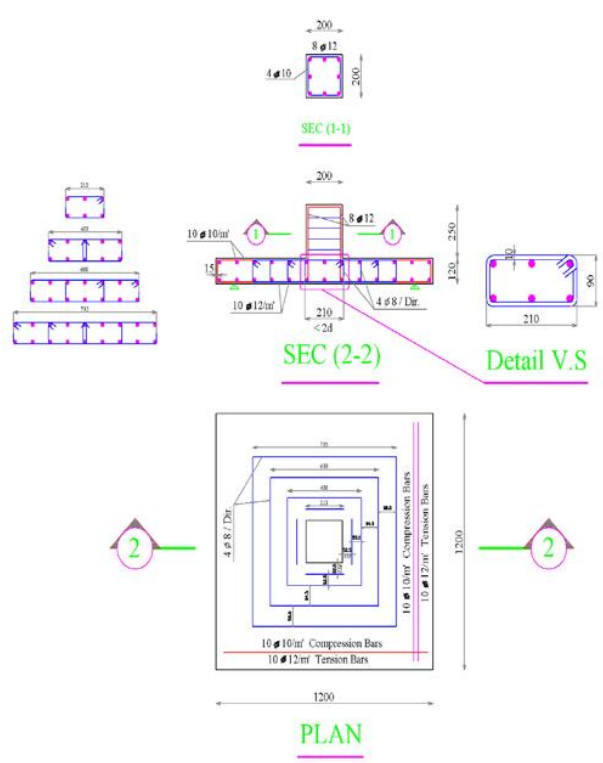

Fig. 7. Test Specimen S10 Represent Group (D)

\section{B. Test Setup and Measurements}

- After the curing period, all slab specimens were moved to execute the concentric punching test stage. The slabs were positioned on top of a designed strong steel frame which had been strengthening by installing steel bracing bars. Four concrete columns were supporting the steel frame which was supporting the slab specimen. The experimental setup was carefully aligned and leveled to overcome any type of failures \& errors.

- The slab specimens were examined using single concentric testing hydraulic jack of a capacity 50 ton as shown in "Fig.8". The procedure of the test loading consists of one loading cycle, which the load rate was increased incrementally by 0.40 ton up to the existence of the first visible crack then the load rate was increased incrementally by 1.00 ton. By the end of each load rate step the load was constant held for 2-3 minutes during which observations, measurements, and marking the visible cracks were achieved. 


\section{Performance of Shear Reinforcement against Punching Shear Loads}

- Electrical strain gauges have been used to measure the strain of the concrete. The electric strain gauges for the concrete were placed as close as possible to the column face in longitudinal and transverse directions for all specimens as shown in

- Three LVDTs have been used in this experiment to measure the vertical displacement (deflection) of the slab. These LVDTs were fixed at the center and quarter of the slab in longitudinal and transverse directions for all specimens as shown in "Fig.9". After each load increment the results of the experiments were recorded, this data includes the load from the jack, the vertical displacement (deflection) that measured from the bottom surface of the slab, the strain of the tension and compression main reinforcement at various locations, and the strain of the shear reinforcement (vertical stirrups).

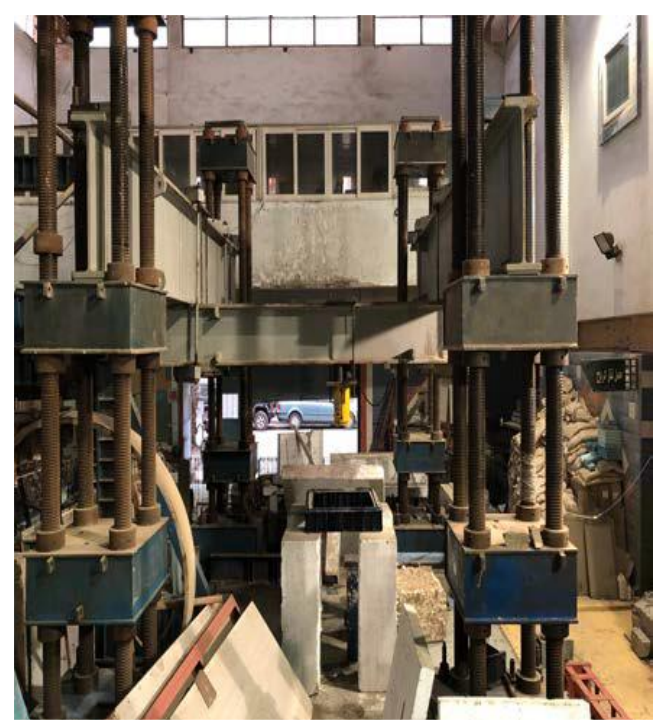

Fig.8. Load Set up for Test Specimens

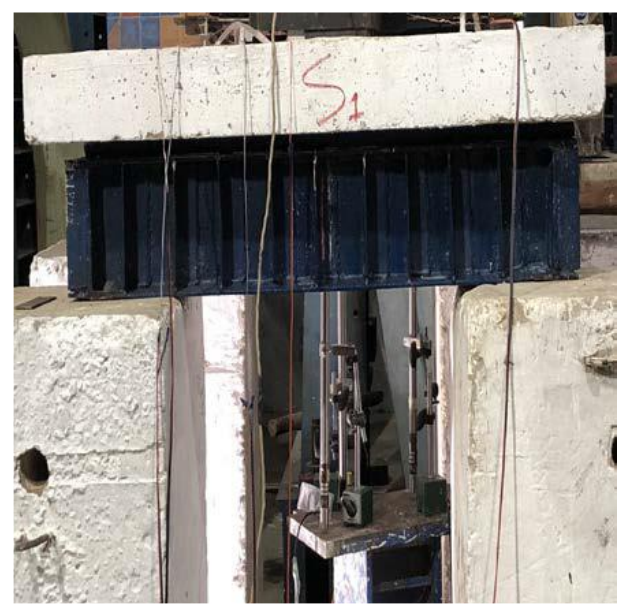

Fig.9. Location of the Three LVDTs

\section{EXPERIMENTAL RESULTS AND DISCUSSIONS}

Despite the fact that analytical modeling is inexpensive and provides the ability to mainly explore the effect of more parameters than experimental programs, experimental test studies remain the most effective and reliable approach.

Experimental testing provides to the researchers the physical information and knowledge about the experimental behavior of the test program. Furthermore, experimental results of the tests are essential in verifying and calibrating the analytical test models.

\section{A. Mode of Failure and Cracking Patterns}

Twelve specimens were loaded to failure in loading control. In general, all specimens exhibited similar crack pattern before the peak point of loading. The crack pattern propagation showed small cracks tangent to the column where first observed around the column and few fine radial cracks started going away from the column faces to the slab edge. Under the increasing load, the radial cracks progressed to the edge while further tangential cracks developed at greater radii.

For each reinforced concrete slab specimen, the crack and failure loads of them are listed in "Table- II", crack pattern and its propagation were recorded at several loading stages and also the slab specimen failures will be discussed and presented in the following paragraphs.

The results of the experiments are presented under the following four parametric groups:

Group (A): containing $\mathrm{S}_{1}, \mathrm{~S}_{2} \& \mathrm{~S}_{3}$ (Existence of Tension RFT; Different Ratio).

Group (B): containing $\mathrm{S}_{4}, \mathrm{~S}_{5} \quad \& \quad \mathrm{~S}_{6}$ (Existence of Compression RFT; Different Ratio).

Group (C): containing S7, S8 \& S9 (Existence of Shear RFT; Different Ratio).

Group (D): containing S10, S11 \& S12 (Existence of Shear RFT; Different Distribution \& Ratio)

The test specimens have been designed to fail in punching shear not to fail in flexural moment. The crack patterns of the test slab specimens ( $S_{1}$ to $\left.S_{12}\right)$ are shown in "Fig.10".

The control slab $\left(\mathrm{S}_{1}\right)$ suddenly failed in punching shear with extended falling of tension concrete, while all the other reinforced slab specimens that strengthened by shear reinforcement failed in a similar manner showing a ductile and gradual punching failure with higher ultimate loads.

Table- II: Cracking and Failure Loads for Each Specimen

\begin{tabular}{|c|c|c|c|c|c|}
\hline $\begin{array}{c}\text { Group } \\
\text { No. }\end{array}$ & $\begin{array}{c}\text { Specimen } \\
\text { No. }\end{array}$ & $\begin{array}{c}\text { First } \\
\text { Crack } \\
\text { Load } \\
\text { ton }\end{array}$ & $\begin{array}{c}\text { Appear } \\
\text { First } \\
\text { Crack } \\
\text { ton }\end{array}$ & $\begin{array}{c}\text { Failure } \\
\text { Load } \\
\text { ton }\end{array}$ & Note \\
\hline \multirow{2}{*}{$\begin{array}{c}\text { Group } \\
\text { (A) }\end{array}$} & $\mathrm{S} 1$ & 7.80 & 9.50 & $\mathbf{2 8 . 7 4}$ & Control \\
\cline { 2 - 6 } & $\mathrm{S} 2$ & 9.50 & 11.00 & $\mathbf{3 1 . 7 5}$ & Reference(A) \\
\hline \multirow{2}{*}{$\begin{array}{c}\text { Group } \\
\text { (B) }\end{array}$} & $\mathrm{S} 3$ & 10.40 & 12.00 & $\mathbf{3 7 . 9 8}$ & ---- \\
\hline \multirow{2}{*}{$\begin{array}{c}\text { Group } \\
\text { (C) }\end{array}$} & $\mathrm{S} 5$ & 9.55 & 11.20 & $\mathbf{3 2 . 1 6}$ & ----- \\
\cline { 2 - 6 } & $\mathrm{S} 6$ & 11.00 & 12.10 & $\mathbf{3 6 . 5 1}$ & Reference(B) \\
\hline \multirow{2}{*}{$\begin{array}{c}\text { Group } \\
\text { (D) }\end{array}$} & $\mathrm{S} 9$ & 11.60 & 12.60 & $\mathbf{3 6 . 8 8}$ & ---- \\
\cline { 2 - 6 } & $\mathrm{S} 10$ & 12.60 & 13.20 & $\mathbf{4 0 . 3 3}$ & Reference(C) \\
\cline { 2 - 6 } & $\mathrm{S} 11$ & 12.90 & 13.80 & $\mathbf{4 2 . 0 5}$ & ------ \\
\hline
\end{tabular}

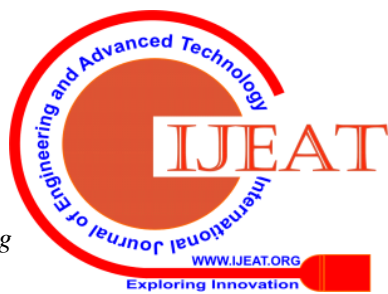




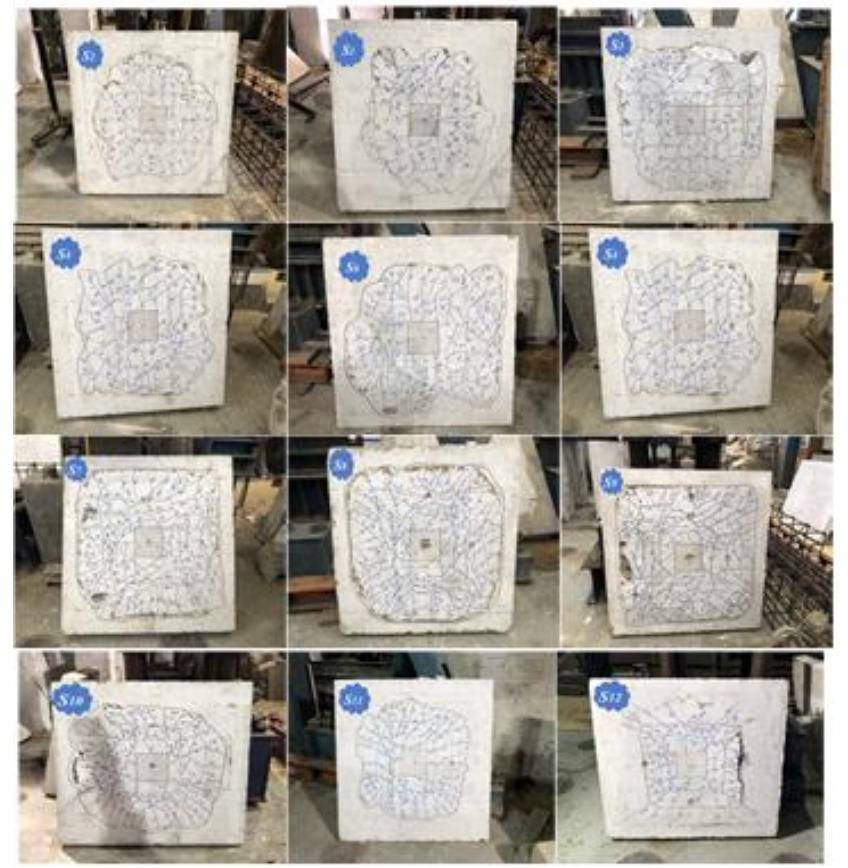

Fig.10. Cracking Patterns of Specimens ( $\mathrm{S}_{1}$ to $\left.\mathrm{S}_{12}\right)$

\section{B. Load - Strain Behavior}

The relationships between load \& strain of each tested specimen for shear reinforcement, slab tension \& compression main reinforcement, and concrete are shown in "Fig. 11" to "Fig.15".

The tested slab specimens were divided into five groups referred to the parameters that the research aimed to study and investigate.

- Group (A): containing $S_{1}, S_{2} \& S_{3}$.

- $\quad$ Group (B): containing $\mathrm{S}_{4}, \mathrm{~S}_{5} \& \mathrm{~S}_{6}$.

- Group (C): containing $S_{7}, S_{8} \&$ S 9

- Group (D): containing $\mathrm{S}_{10}, \mathrm{~S}_{11} \& \mathrm{~S}_{12}$.

- Group (R): containing $\mathrm{S}_{2}, \mathrm{~S}_{5}, \mathrm{~S}_{7}$ \& S10 (Reference Specimen Slabs for the four groups).

"Fig.11" indicates that the specimen $\mathrm{S}_{3}$ has higher strain values compared to the specimens $S_{1} \& S_{2}$ for all loading stages till the failure. Furthermore, specimen $S_{3}$ indicates inconsiderable increase in the slab punching shear resistance.

"Fig.12" indicates that at the same load for example 25 ton the strain of the compression main RFT is changed for specimens $\mathrm{S}_{4}, \mathrm{~S}_{5} \& \mathrm{~S}_{6}$ to be $(-0.000025,-0.000054$ \& 0.000059 ) respectively, it was concluded from these values that the specimen $\mathrm{S}_{6}$ shows higher compression RFT strain value compared to slab specimens $\left(\mathrm{S}_{4} \& \mathrm{~S}_{5}\right)$. punching shear strain value (0.000496) compared to the specimens $\mathrm{S}_{7} \&$ S8 $(0.00041,0.000443)$ respectively besides it has also the highest punching shear load value (42.05 ton) compared to the other specimens which have lower shear load values (38.57, 40.33 ton) for $\mathrm{S}_{7} \&$ S8 respectively.

"Fig.14" indicates that the specimen $\mathrm{S}_{12}$ has the highest punching shear strain value $(0.000952)$ compared to all specimens and especially $(0.000519,0.000784)$ for $S_{10} \& S_{11}$ respectively besides it has also the highest punching shear load value (44.43 ton) compared to all specimens and especially (40.10, 41.77 ton) for $S_{10} \& S_{11}$ respectively.

"Fig.15" indicates that the specimen $\mathrm{S}_{10}$ has the highest concrete strain value $(-0.001528)$ for all loading stages
"Fig.13" indicates that the specimen $\mathrm{S}_{9}$ has the highest

compared to specimens $\mathrm{S}_{2}, \mathrm{~S}_{5} \& \mathrm{~S}_{7}$ which have lower strain values of $(-0.001156,-0.001284 \&-0.001347)$ respectively. In addition to this, specimen $\mathrm{S}_{10}$ has also the highest punching

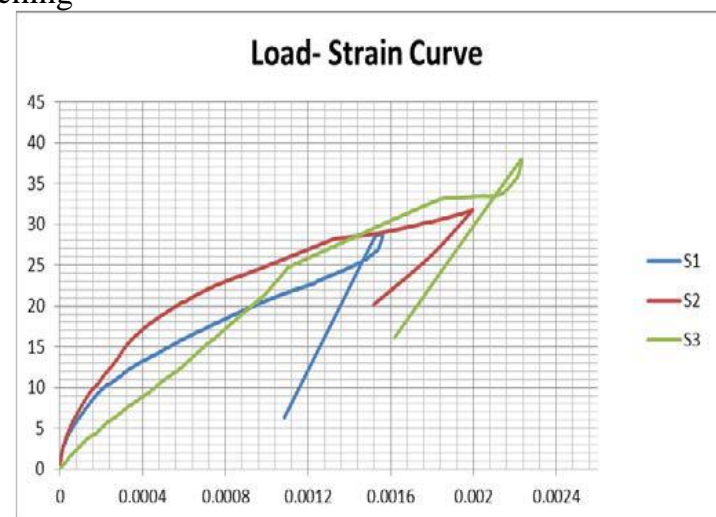

Fig.11. Load-Strain Curve at Tension Side for Group (A) - (Under Column)

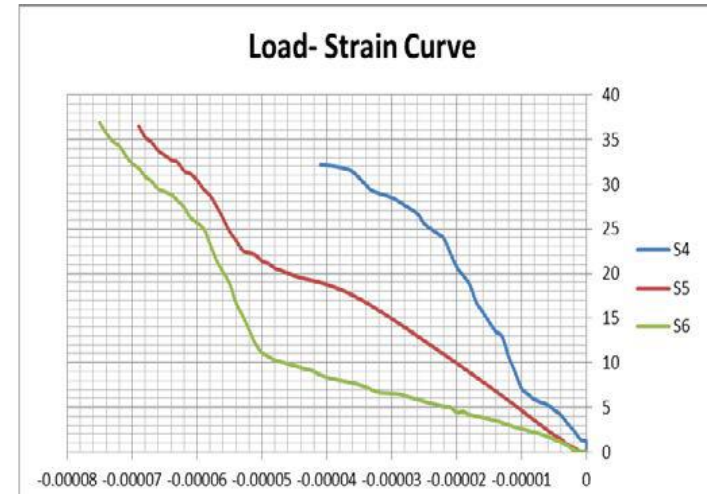

Fig.12. Load-Strain Curve at Compression Side for Group (B)

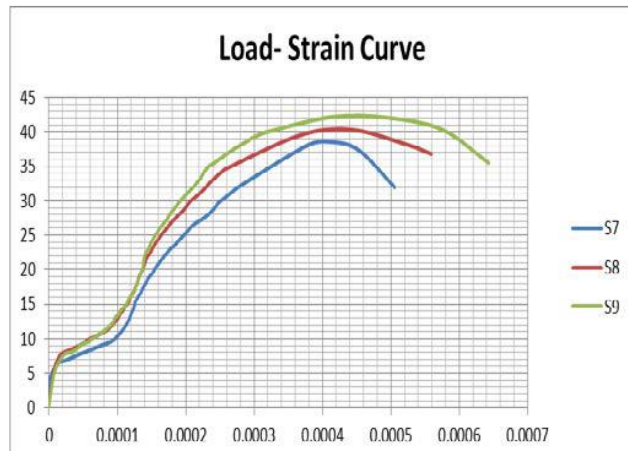

Fig.13. Load-Strain Curve of Shear RFT for Group (C)

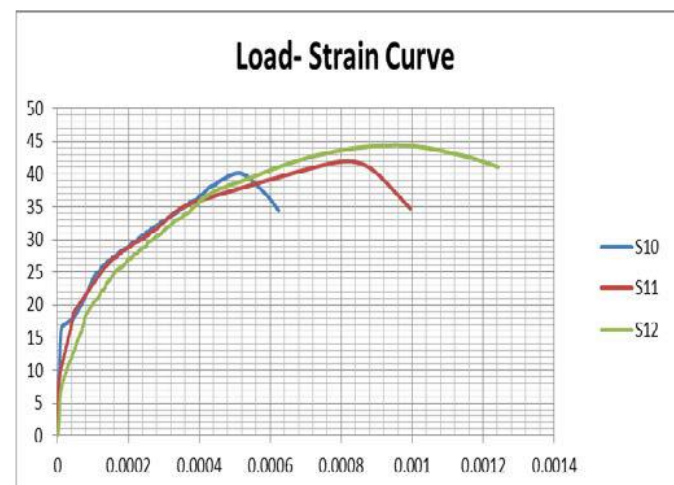

Fig.14. Load-Strain Curve of Shear RFT for Group (D) 


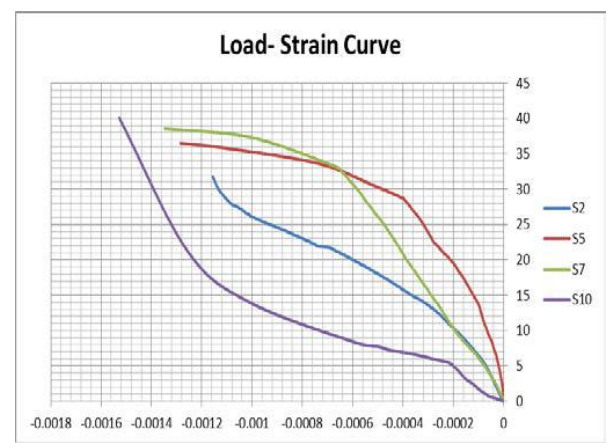

Fig.15. Load-Strain Curve of Concrete for Group (R)

\section{Load - Deflection Behavior}

The deflections which have been measured by dial gauges (LVDTs) are shown in the center of the slab (under column) as shown in "Fig.16" and at distance $0.25 \mathrm{~L}$ from column center.

"Fig.16" indicates that specimen S10 has the higher value of deflection compared to the reference specimens S2, S5 \& S7. Therefore, it has the highest deflection of $8.591 \mathrm{~mm}$ (under column) compared to the specimens S2, S5 \& S7 of (6.192, 6.910 \& $8.275 \mathrm{~mm})$ respectively.

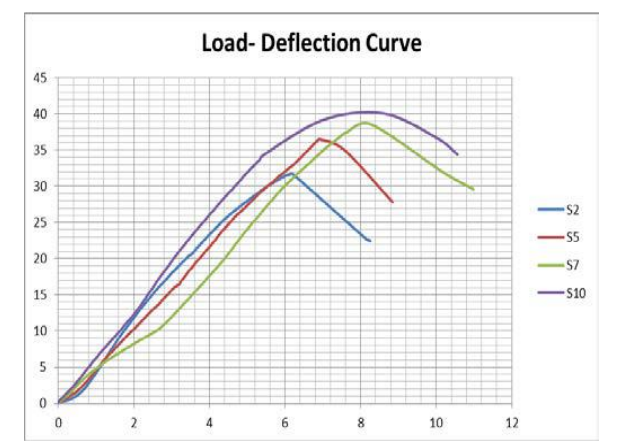

Fig.16. Load-Deflection Curve for Group (R)

\section{FINITE ELEMENT MODELING}

Finite element models (FEM) were created using the software Abaqus/Standard in order to simulate the slabcolumn connection specimens which were presented before. After the simulations the results were presented and compared with the experiments in terms of shear strength, strains in tension, compression \& shear RFT and deflection.

\section{A. Model Discretization Method}

- A 3-D Numerical model using FEM- ABAQUS 2017 was generated to examine a complete model taking to account flexural RFT, shear RFT \& Concrete elements as shown in "Fig.17".

- 12 models were adopted to simulate the experimental tests performed on specimens as discussed in the experimental work.

B. Loading - Method

- The column's top surface was imposed to a Vertical Downward Displacement instead of applying a concentric load as shown in "Fig.18".

- The displacement was increased incrementally and Abaqus controls the rate of the displacement during the simulation.

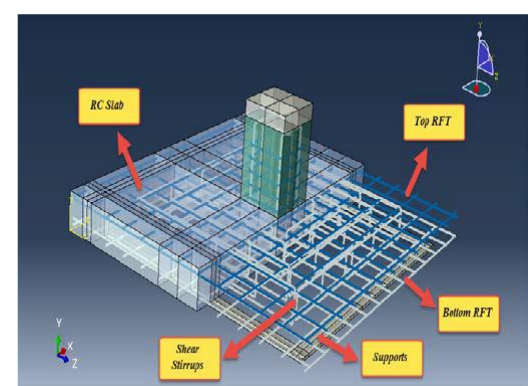

Fig.17 Different Types of the Used Elements

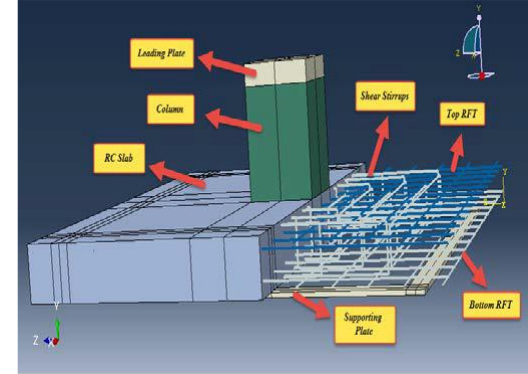

Fig.18. Embedded Steel Elements in Concrete Slab Element

\section{Model Validation}

The results from simulation are compared with the results of the experimental program.

Specimen ( $\left.\mathbf{S}_{2}\right)$ represents Group (A);

- The maximum load reached by the ABAQUS is 30.218 tons, which is lower than the measured strength 31.75 tons, approximately 4.82\% lower. The corresponding calculated deflection under column was $6.477 \mathrm{~mm}$ which is higher than the measured column displacement $6.192 \mathrm{~mm}$, approximately $4.6 \%$ higher. The variation appeared between the model and the test results in the maximum load and deflection at the failure is because of the difference in material definition, specially the definition of the concrete properties as shown in "Fig.19".

- Due to the unavailability of the cutting machine for the interior slabs the inclined cracks were not able to observed, but its projection clear on the bottom side of the slab which was found approximately on $3.4 \mathrm{~d}$ from the column periphery. Failure surfaces in specimen $\left(\mathrm{S}_{2}\right)$ experimental and model were taken after the test. As shown in "Fig.20" the failure surface of the Finite element model seems to be a similar to the actual failure surface of the experimental specimen.

Specimen ( $\mathbf{S}_{5}$ ) represents Group (B);

- The maximum load reached by the ABAQUS is 38.28 tons, which is higher than the measured strength 36.51 tons, approximately $4.85 \%$ higher. The corresponding calculated deflection under column was $6.377 \mathrm{~mm}$ which is lower than the measured column displacement $6.91 \mathrm{~mm}$, approximately $7.72 \%$ lower. The variation appeared between the model and the test results in the maximum load and deflection at the failure is because of the difference in material definition, specially the definition of the concrete properties as shown in "Fig.21". 
- Due to the unavailability of the cutting machine for the interior slabs the inclined cracks were not able to observed, but its projection clear on the bottom side of the slab which was found approximately on 3.38d from the column periphery. Failure surfaces in specimen $\left(\mathrm{S}_{5}\right)$ experimental and model were taken after the test. As shown in "Fig.22" the failure surface of the Finite element model seems to be a similar to the actual failure surface of the experimental specimen.

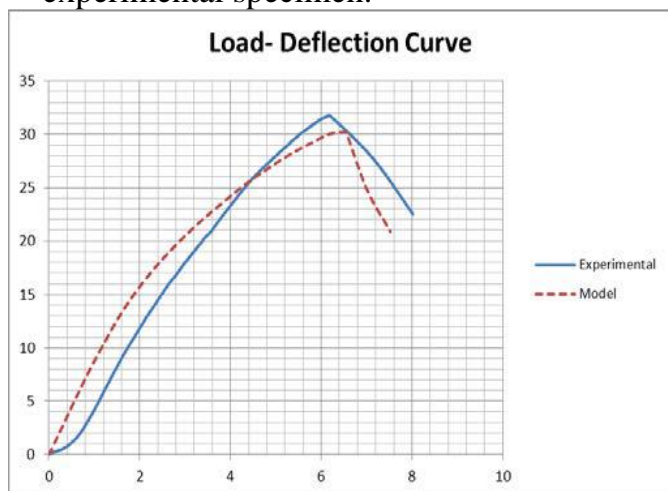

Fig.19. Experimental and Simulation Results for Specimen $\left(\mathrm{S}_{2}\right)$

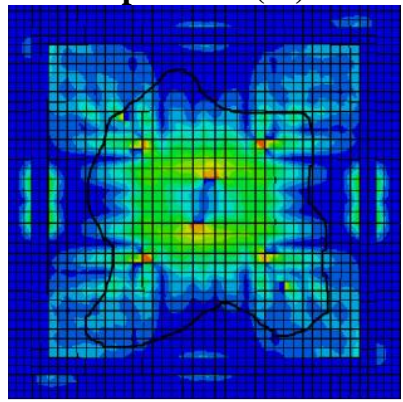

Fig.20. Simulation Failure Surface for Specimen $\left(\mathrm{S}_{2}\right)$

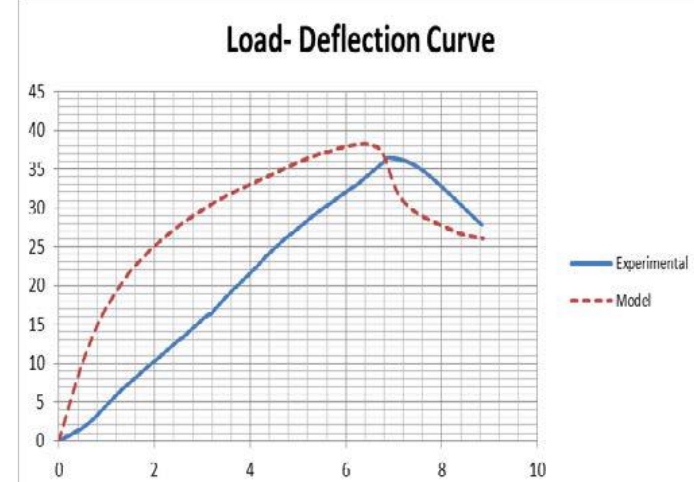

Fig.21. Experimental and Simulation Results for Specimen ( $\left.\mathrm{S}_{5}\right)$

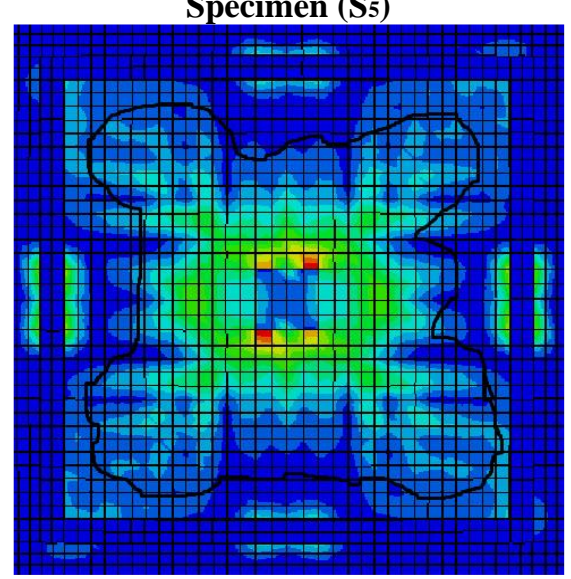

Fig.22. Simulation Failure Surface for Specimen $\left(\mathrm{S}_{5}\right)$

Retrieval Number: B3975129219/2019@BEIESP

DOI: 10.35940/ijeat.B3975.129219

Journal Website: www.ijeat.org
Specimen (S $\mathbf{7}$ ) represents Group (C);

- The maximum load reached by the ABAQUS is 39.131 tons, which is higher than the measured strength 38.57 tons, approximately $1.46 \%$ higher. The corresponding calculated deflection under column was $7.677 \mathrm{~mm}$ which is lower than the measured column displacement $8.275 \mathrm{~mm}$, approximately $7.23 \%$ lower. The variation appeared between the model and the test results in the maximum load and deflection at the failure is because of the difference in material definition, specially the definition of the concrete properties as shown in "Fig.23".

- Due to the unavailability of the cutting machine for the interior slabs the inclined cracks were not able to observed, but its projection clear on the bottom side of the slab which was found approximately on $3.7 \mathrm{~d}$ from the column periphery. Failure surfaces in specimen $\left(\mathrm{S}_{7}\right)$ experimental and model were taken after the test. As shown in "Fig.24" the failure surface of the Finite element model seems to be a similar to the actual failure surface of the experimental specimen.

Specimen (S10) represents Group (D);

- The maximum load reached by the ABAQUS is 41.954 tons, which is higher than the measured strength 40.1 tons, approximately $4.62 \%$ higher. The corresponding calculated deflection under column was $8.096 \mathrm{~mm}$ which is higher than the measured column displacement $7.591 \mathrm{~mm}$, approximately $6.66 \%$ higher. The variation appeared between the model and the test results in the maximum load and deflection at the failure is because of the difference in material definition, specially the definition of the concrete properties as shown in "Fig.25".

- Due to the unavailability of the cutting machine for the interior slabs the inclined cracks were not able to observed, but its projection clear on the bottom side of the slab which was found approximately on $3.5 \mathrm{~d}$ from the column periphery. Failure surfaces in specimen $\left(\mathrm{S}_{10}\right)$ experimental and model were taken after the test. As shown in "Fig.26" the failure surface of the Finite element model seems to be a similar to the actual failure surface of the experimental specimen

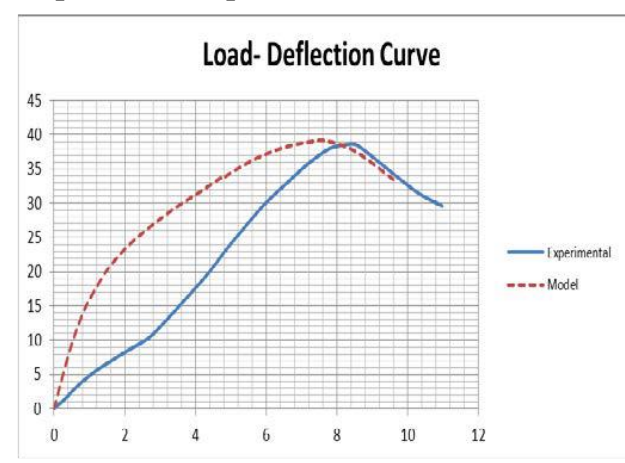

Fig.23. Experimental and Simulation Results for Specimen $\left(\mathrm{S}_{7}\right)$ 


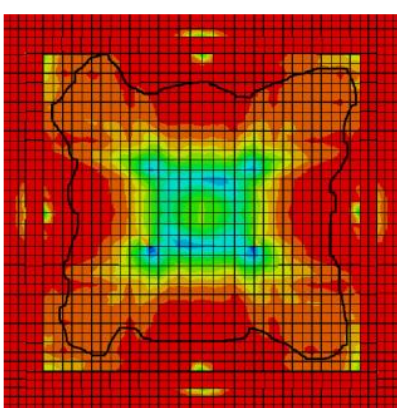

Fig.24. Experimental and Simulation Results for Specimen $\left(\mathrm{S}_{7}\right)$

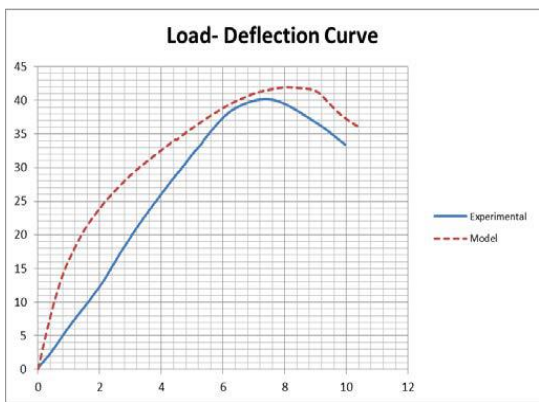

Fig.25. Simulation Failure Surface for Specimen $\left(\mathrm{S}_{10}\right)$

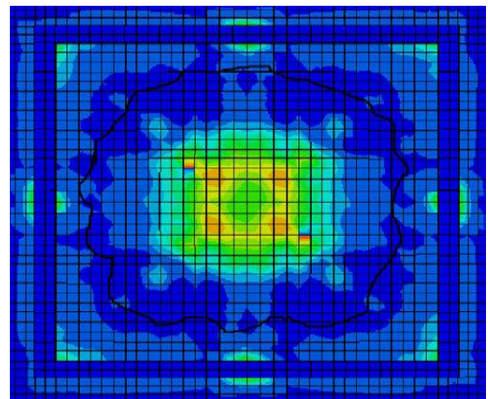

Fig.26. Simulation Failure Surface for Specimen $\left(\mathrm{S}_{10}\right)$

\section{General Remarks}

According to the FE models of each tested slab, it's obvious that these values show good agreement between the FEM and the experimental results from the failure load and displacement under column as shown in "Table- III".

Table- III: Comparison between Experimental Results and FEM Results

\begin{tabular}{|c|c|c|c|c|c|c|c|}
\hline $\begin{array}{c}\text { Group } \\
\text { No. }\end{array}$ & $\begin{array}{c}\text { Specimen } \\
\text { No. }\end{array}$ & $\begin{array}{c}\Delta_{\text {test }} \\
(\mathbf{m m})\end{array}$ & $\begin{array}{l}\Delta_{\text {FEM }} \\
(\mathbf{m m})\end{array}$ & $\begin{array}{c}P_{\text {test }} \\
\text { (ton) }\end{array}$ & $\begin{array}{l}P_{\text {fEM }} \\
\text { (ton) }\end{array}$ & $\begin{array}{l}\Delta_{\text {test }} / \\
\Delta_{\text {FEM }}\end{array}$ & $\begin{array}{l}\mathbf{P}_{\text {test }} / \\
\mathbf{P}_{\text {FEM }}\end{array}$ \\
\hline \multirow{3}{*}{$\begin{array}{l}\text { Group } \\
\text { (A) }\end{array}$} & S1 & 6.345 & 6.752 & 28.74 & 28.715 & 0.94 & 1.00 \\
\hline & S2 & 6.192 & 6.477 & 31.75 & 30.218 & 0.96 & 1.05 \\
\hline & S3 & 5.255 & 4.855 & 37.98 & 35.448 & 1.08 & 1.07 \\
\hline \multirow{3}{*}{$\begin{array}{l}\text { Group } \\
\text { (B) }\end{array}$} & S4 & 5.823 & 6.202 & 32.16 & 30.364 & 0.94 & 1.06 \\
\hline & S5 & 6.91 & 6.377 & 36.51 & 38.28 & 1.08 & 0.95 \\
\hline & S6 & 7.03 & 6.545 & 36.88 & 38.529 & 1.07 & 0.96 \\
\hline \multirow{3}{*}{$\begin{array}{l}\text { Group } \\
\text { (C) }\end{array}$} & S7 & 8.275 & 7.677 & 38.57 & 39.131 & 1.08 & 0.99 \\
\hline & S8 & 8.394 & 8.089 & 40.33 & 39.643 & 1.04 & 1.02 \\
\hline & S9 & 8.514 & 8.808 & 42.05 & 40.112 & 0.97 & 1.05 \\
\hline \multirow{3}{*}{$\begin{array}{l}\text { Group } \\
\text { (D) }\end{array}$} & $\mathrm{S} 10$ & 7.591 & 8.096 & 40.1 & 41.954 & 0.94 & 0.96 \\
\hline & S11 & 12.28 & 13.326 & 41.77 & 42.739 & 0.92 & 0.98 \\
\hline & S12 & 14.99 & 14.663 & 44.43 & 44.559 & 1.02 & 1.00 \\
\hline $\begin{array}{l}\text { Mean } \\
\text { Value }\end{array}$ & & & & & & 1.003 & 1.008 \\
\hline
\end{tabular}

\section{PROVISIONS FOR SYMMETRICAL PUNCHING SHEAR RESISTANCE TOWARDS DIFFERENT INTERNATIONAL CODES}

A comparison has been made between the different values of punching shear stress by using experimental investigation and these values are deduced by using equations that proposed in these different international codes. The resistance of the punching shear for reinforced flat slab is usually made by adopting the provisions of these different international codes. Counting on the empirical equations used by codes these provisions are obtained. Some of the most important used shear design equations for reinforcement concrete structures are as following:

- Eurocode (2):2014 [15].

- American Concrete Institute (ACI 318-14) [16].

- ECP 203-2018 [17].

A. Comparison with Eurocode (2):2014

The comparison between the experimental results \& the Eurocode (2) results are the same results like BS \& DIN codes results. So according to the comparison of Eurocode (2):2014 provision, this comparison listed in "Table- IV" is between concrete punching shear strength $\left(\mathrm{V}_{\mathrm{cd}}\right)$ that had been calculated by slab specimens ( $\mathrm{S}_{1}$ to $\mathrm{S}_{6}$ ) where these specimens don't contain shear reinforcement and between nominal shear strength $\left(\mathrm{V}_{\mathrm{sd}}\right)$ that had been calculated by the rest of test specimens ( $\mathrm{S}_{7}$ to $\mathrm{S}_{12}$ ) where these specimens contain shear reinforcement (Vertical Stirrups) with different parameters.

The following conclusions can be observed:

- The conservatism degree minimizes with using shear reinforcement.

- By adding tension and compression main reinforcement to the design equation (avg) maximizes the resistance of the punching shear in the experimental specimen test results.

- The ratios of the loads in the experimental test were as predicted where $\left(\mathrm{V}_{\text {test }} / \mathrm{VEC}_{\mathrm{EC}}\right)$ greater than one, so these ratios indicate that they lie in a safe side of the test comparison with Eurocode (2):2014 provision.

\section{B. Comparison with ACI 318-14}

According to the comparison of ACI 318-14 code provision, this comparison listed in "Table- IV" is between concrete punching shear strength (Vuc) that had been calculated by slab specimens ( $S_{1}$ to $S_{6}$ ) where these specimens don't contain shear reinforcement and between nominal shear strength $(\mathrm{Vu})$ that had been calculated by the rest of test specimens ( $S_{7}$ to $\left.S_{12}\right)$ where these specimens contain shear reinforcement (Vertical Stirrups) with different parameters.

The following conclusions can be observed:

- The conservatism degree minimizes with using shear reinforcement.

- The ratios of the loads in the experimental test were as predicted where (Vtest / V $\mathrm{ACI}$ ) greater than one, so these ratios indicate that they lie in a safe side of the test comparison with ACI 318-14 code provision 
C. Comparison with ECP 203-2018

According to the comparison of ECP 203-2018 code provision, this comparison listed in "Table- IV" is between concrete punching shear strength ( $\mathrm{q}_{\text {cup }}$ ) that had been calculated by slab specimens ( $\mathrm{S}_{1}$ to $\left.\mathrm{S}_{6}\right)$ where these specimens don't contain shear reinforcement and between nominal shear strength ( $q_{\text {up }}$ ) that had been calculated by the rest of test specimens ( $\mathrm{S}_{7}$ to $\mathrm{S}_{12}$ ) where these specimens contain shear reinforcement (Vertical Stirrups) with different parameters.

The following conclusions can be observed:

- The conservatism degree minimizes with using shear reinforcement.

- The ratios of the loads in the experimental test were as predicted where (Vtest / VECP) greater than one, so these ratios indicate that they lie in a safe side of the test comparison with the proposed ECP 2032018 code provision.

"Table- IV" shows the comparison results between data obtained from experimental and the previous three codes.

Table- IV: Comparison between International Codes Predicted Shear Load \& Experimental Failure Load

\begin{tabular}{|c|c|c|c|c|c|c|c|c|}
\hline $\begin{array}{c}\text { Grou } \\
\mathbf{p} \\
\text { No. }\end{array}$ & $\begin{array}{c}\text { Specim } \\
\text { en } \\
\text { No. }\end{array}$ & $\left.\begin{array}{c}V_{\text {test }} \\
(\mathbf{m m}\end{array}\right)$ & $\begin{array}{c}\mathrm{V}_{\mathrm{EC} .} \\
2 \\
(\mathbf{m m} \\
)\end{array}$ & $\left.\begin{array}{c}\mathrm{V}_{\mathrm{ACI}} \\
(\mathrm{mm}\end{array}\right)$ & $\begin{array}{c}\mathbf{V}_{\mathrm{EC}} \\
\mathbf{P} \\
(\mathrm{mm} \\
)\end{array}$ & $\begin{array}{c}\mathbf{V}_{\text {test }} \\
/ \\
\mathbf{V}_{\mathrm{EC} .} \\
2\end{array}$ & $\begin{array}{c}\mathbf{V}_{\text {test }} \\
/ \\
\mathbf{V}_{\mathrm{ACI}}\end{array}$ & $\begin{array}{c}\mathbf{V}_{\text {test }} \\
/ \mathbf{V}_{\text {EC }} \\
\quad \mathbf{P}\end{array}$ \\
\hline \multirow{3}{*}{$\begin{array}{l}\text { Grou } \\
\text { p (A) }\end{array}$} & S1 & $\begin{array}{c}28.7 \\
4\end{array}$ & $\begin{array}{c}21.5 \\
4\end{array}$ & $\begin{array}{c}15.5 \\
4\end{array}$ & $\begin{array}{c}18.1 \\
0\end{array}$ & $\begin{array}{c}1.33 \\
4\end{array}$ & $\begin{array}{c}1.85 \\
0\end{array}$ & $\begin{array}{c}1.58 \\
8\end{array}$ \\
\hline & S2 & $\begin{array}{c}31.7 \\
5\end{array}$ & $\begin{array}{c}24.3 \\
3\end{array}$ & $\begin{array}{c}15.5 \\
4\end{array}$ & $\begin{array}{c}18.1 \\
0\end{array}$ & $\begin{array}{c}1.30 \\
5\end{array}$ & $\begin{array}{c}2.04 \\
3\end{array}$ & $\begin{array}{c}1.75 \\
4\end{array}$ \\
\hline & S3 & $\begin{array}{c}37.9 \\
8\end{array}$ & $\begin{array}{c}29.1 \\
1\end{array}$ & $\begin{array}{c}15.5 \\
4\end{array}$ & $\begin{array}{c}18.1 \\
0\end{array}$ & $\begin{array}{c}1.30 \\
5\end{array}$ & $\begin{array}{c}2.44 \\
4\end{array}$ & $\begin{array}{c}2.09 \\
8\end{array}$ \\
\hline \multirow{3}{*}{$\begin{array}{l}\text { Grou } \\
\text { p (B) }\end{array}$} & S4 & $\begin{array}{c}32.1 \\
6\end{array}$ & $\begin{array}{c}25.9 \\
2\end{array}$ & $\begin{array}{c}15.5 \\
4\end{array}$ & $\begin{array}{c}18.1 \\
0\end{array}$ & $\begin{array}{c}1.24 \\
1\end{array}$ & $\begin{array}{c}2.07 \\
0\end{array}$ & $\begin{array}{c}1.77 \\
7\end{array}$ \\
\hline & S5 & $\begin{array}{c}36.5 \\
1\end{array}$ & $\begin{array}{c}26.7 \\
5 \\
\end{array}$ & $\begin{array}{c}15.5 \\
4\end{array}$ & $\begin{array}{c}18.1 \\
0\end{array}$ & $\begin{array}{c}1.36 \\
5\end{array}$ & $\begin{array}{c}2.35 \\
0 \\
\end{array}$ & $\begin{array}{c}2.01 \\
7 \\
\end{array}$ \\
\hline & S6 & $\begin{array}{c}36.8 \\
8\end{array}$ & $\begin{array}{c}27.7 \\
0\end{array}$ & $\begin{array}{c}15.5 \\
4\end{array}$ & $\begin{array}{c}18.1 \\
0\end{array}$ & $\begin{array}{c}1.33 \\
1\end{array}$ & $\begin{array}{c}2.37 \\
3\end{array}$ & $\begin{array}{c}2.03 \\
8\end{array}$ \\
\hline \multirow{3}{*}{$\begin{array}{l}\text { Grou } \\
\text { p (C) }\end{array}$} & S7 & $\begin{array}{c}38.5 \\
7 \\
\end{array}$ & $\begin{array}{c}36.5 \\
7 \\
\end{array}$ & $\begin{array}{c}27.6 \\
2 \\
\end{array}$ & $\begin{array}{c}28.0 \\
8\end{array}$ & $\begin{array}{c}1.05 \\
5\end{array}$ & $\begin{array}{c}1.40 \\
0\end{array}$ & $\begin{array}{c}1.37 \\
4 \\
\end{array}$ \\
\hline & S8 & $\begin{array}{c}40.3 \\
3\end{array}$ & $\begin{array}{c}38.8 \\
0\end{array}$ & $\begin{array}{c}38.6 \\
5\end{array}$ & $\begin{array}{c}39.3 \\
3\end{array}$ & 1.04 & $\begin{array}{c}1.04 \\
3\end{array}$ & $\begin{array}{c}1.02 \\
5\end{array}$ \\
\hline & S9 & $\begin{array}{c}42.0 \\
5\end{array}$ & $\begin{array}{c}41.5 \\
0\end{array}$ & $\begin{array}{c}38.6 \\
5\end{array}$ & $\begin{array}{c}39.3 \\
3\end{array}$ & $\begin{array}{c}1.01 \\
3\end{array}$ & $\begin{array}{c}1.08 \\
8\end{array}$ & $\begin{array}{c}1.07 \\
0\end{array}$ \\
\hline \multirow{3}{*}{$\begin{array}{l}\text { Grou } \\
\text { p (D) }\end{array}$} & S10 & $\begin{array}{c}40.1 \\
0\end{array}$ & $\begin{array}{c}38.4 \\
0\end{array}$ & $\begin{array}{c}31.1 \\
0\end{array}$ & $\begin{array}{c}31.5 \\
2\end{array}$ & $\begin{array}{c}1.04 \\
4\end{array}$ & $\begin{array}{c}1.28 \\
9\end{array}$ & $\begin{array}{c}1.27 \\
2 \\
\end{array}$ \\
\hline & S11 & $\begin{array}{c}41.7 \\
7 \\
\end{array}$ & $\begin{array}{c}40.2 \\
0 \\
\end{array}$ & $\begin{array}{c}38.6 \\
5 \\
\end{array}$ & $\begin{array}{c}38.9 \\
7 \\
\end{array}$ & 1.04 & $\begin{array}{c}1.08 \\
1 \\
\end{array}$ & $\begin{array}{c}1.07 \\
2 \\
\end{array}$ \\
\hline & S12 & $\begin{array}{c}44.4 \\
3\end{array}$ & $\begin{array}{c}43.3 \\
6\end{array}$ & $\begin{array}{c}38.6 \\
5\end{array}$ & $\begin{array}{c}40.5 \\
0\end{array}$ & $\begin{array}{c}1.00 \\
2\end{array}$ & $\begin{array}{c}1.12 \\
4\end{array}$ & $\begin{array}{c}1.07 \\
3\end{array}$ \\
\hline $\begin{array}{c}\text { Mea } \\
\text { n } \\
\text { Valu } \\
\text { e }\end{array}$ & & & & & & $\begin{array}{c}1.17 \\
3\end{array}$ & $\begin{array}{c}1.68 \\
0\end{array}$ & $\begin{array}{c}1.51 \\
3\end{array}$ \\
\hline
\end{tabular}

\section{CONCLUSIONS}

This research examined the reinforced concrete flat slabs behavior under concentric punching loading that investigated by using test experiments. The results of the test experiments showed the slab specimens performance with using different shear reinforcement types and several distribution techniques.

An experimental investigation of the punching shear performance of flat slabs with and without shear reinforcement has been conducted. Effect of the tensile and compressive steel on the punching shear behavior has been also investigated. Various code provisions on the punching shear have been examined. Non-linear finite element analyses have been carried out on the test slabs.

According to the experimental, numerical \& theoretical investigation results which were executed in this research; the following important conclusions can be drawn:

1) Flexural reinforcement ratio especially in tension side had a noticeable effect on the mode of failure and ultimate punching capacity of flat slabs.

2) Flexural reinforcement ratio and shear reinforcement had insignificant effect on the cracking loads of the test specimens, with a noticeable effect on the cracking patterns and ductility.

3) The ultimate load of test specimens increased as the tensile reinforcement increased. The enhancement in the ultimate loads due to increasing tension RFT ratio was ranging between $40 \%$ and $60 \%$.

4) Slightly enhancement up to (10\%) in ultimate loads was observed as a result of increasing compressive RFT ratio.

5) Provision of shear reinforcement was shown to increase the perimeter of the failure. Specimens with shear reinforcement (Vertical Stirrups) failed at larger perimeters than slabs without shear reinforcement.

6) By using the new distribution of shear RFT, the strength of punching shear of slab-column connections has been increased at Group (D) and according to the loaddeflection relationship curves of the specimens showed that the deflection increases directly proportional with increasing the shear RFT ratio with constant tension \& compression RFT ratio.

7) According to the load- strain relationship curves of the specimens of Group (D) showed that the strain of the tension \& compression RFT decreases while the strain of the shear RFT increases directly proportional with increasing the shear RFT ratio the same like Group $(\mathrm{C})$ but by using the new distribution of shear RFT the diagonal cracks at the tension face of the specimen have been minimized directly proportional with increasing the shear RFT ratio.

8) To the range of the test parameters investigated, the application of non-linear finite element analysis using ABAQUS 2017 package yielded satisfactory load-carrying capacities and load-deflection responses with acceptable cracking loads.

9) Codes comparison indicates a significant variation in the punching shear predictions from code to another. Eurocode (2):2014 shows the most effective code for punching shear capacity specially in case of using shear reinforcement due to adding tension and compression main reinforcement (avg) that maximizes the resistance of the punching shear in the experimental specimen test results. While the predictions following the DIN 1045-1:2008 \& BS 8110-1:2007 codes are closet to the experimental results. On the other hand; ECP 203-2018, ACI 318-14 \& CSA A23.3-1 provisions show the least effective codes for punching shear capacity due to not adding tension and compression main reinforcement (avg) to the design equation. 


\section{Performance of Shear Reinforcement against Punching Shear Loads}

\section{REFERENCES}

1. Tassinari L., Lips S., Muttoni A., Fernández Ruiz M., Applications of bent-up bars as shear and integrity reinforcement in R/C slabs, Proceedings of the fib Symposium Prague 2011, pp. 631-634, Prague, Czech Republic, 2011.

2. Min-Yuan Cheng, "Punching Shear Strength and Deformation Capacity of Fiber Reinforcement Concrete Slab-Column Connections Under Earthquake-Type Loading", 2009.

3. ACI Committee 318, "Building Code Requirements for Reinforced Concrete (ACI 318-63)", American Concrete Institute, Detroit, Michigan, 1963.

4. ACI 318, "Building Code Requirement for Structural Concrete and Commentary (ACI 318-02)". American Concrete Institute, Farmington Hills, Mich.

5. Islam, S. and Park, R., "Tests of Slab-Column Connections with Shear and Unbalanced Flexure", Journal of the Structural Division, Proceedings of the American Society of Civil Engineers, Vol. 102, No. ST3, March, 1976, pp. 549-569.

6. Dilger, W. H. and Ghali, A., "Shear Reinforcement For Concrete Slabs", Journal of Structural Division, Proceedings of the American Society of Civil Engineers, Vol. 107, No. 12, Dec., 1981, pp. 24032420.

7. Corley, W. G. and Hawkins, N. M., "Shear head Reinforcement for Slabs", ACI Journal, Vol. 65, No. 10, October, 1968, pp. 811-824.

8. Yamada, T.; Nanni, A.; and Endo, K., "Punching Shear Resistance of Flat Slabs: Influence of Reinforcement Type and Ratio," ACI Structural Journal, V. 89, No. 4, July-Aug. 1992, pp. 555-563.

9. Ramdane, K.E. 1996, "Punching Shear of High Performance Concrete Slabs". 4th International Symposium on Utilization of Highstrength/High-performance Concrete. Paris, 1996, pp. 1015-1026.

10. Leandro M. Trautwein, Túlio N. Bittencourt, Ronaldo B. Gomes, and João Carlos Della Bella, 2011, "Punching Strength of Flat Slabs with Unbraced Shear Reinforcement.", ACI Structural Journal, V. 108, No. 2, March-April 2011., pp. 197-205.

11. Carsten Siburg and Josef Hegger, 2014, "Experimental investigations on the punching behaviour of reinforced concrete footings with structural dimensions." Structural Concrete 15 (2014), No. 3): 331339.

12. Taehun Ha, Myung-Ho Lee, Jonghwan Park and Dae-Jin Kim, 2015, "Effects of openings on the punching shear strength of RC flat-plate slabs without shear reinforcement". Published online 30 March 2015 in Wiley Online Library (wileyonlinelibrary.com/journal/tal).

13. Ahmed Mohamed Issa, "Performance of Shear Reinforcement against Punching Shear Loads" 2019.

\section{AUTHORS PROFILE}

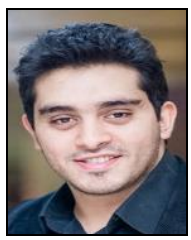

Ahmed M. Issa

B.Sc. Civil Engineering Department, Cairo University, Egypt.

M.Sc. Civil Engineering Department, Cairo University, Egypt.

Research Fields: Reinforced Concrete - strength of materials - Repairs of Concrete Structures.

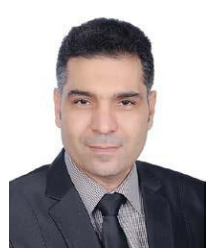

Mohamed M. Salem

B.Sc. Civil Engineering Department, Cairo University Egypt.

M.Sc. Civil Engineering Department, Cairo University: Egypt.

Ph.D. Leibniz University Hannover, Germany.

Research Fields: Reinforced Concrete - Fiber Reinforced Concrete Strengthening- Long-Term behavior.

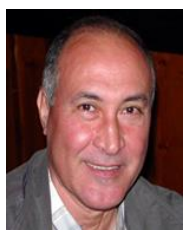

Mohamed T. Mostafa

B.Sc. Civil Engineering Department, Cairo University Egypt.

M.Sc. Duke University, Durham, North Carolina, USA.. Ph.D. North Carolina State University, Raleigh, Nortr Carolina, USA.

Research Fields: Reinforced Concrete - Prestressed

Concrete - Fiber Reinforced Concrete Strengthening.

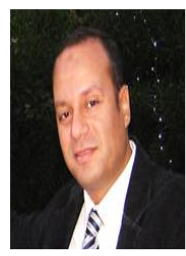

Hamed M. Hadhoud

B.Sc. Civil Engineering Department, Cairo University Egypt.

M.Sc. Civil Engineering Department, Cairo University Egypt.

Ph.D. The University of Tokyo, Japan.

Research Fields: Nonlinear Analysis of Reinforced Concrete - Behavior of Reinforced Concrete under Extreme Loads.

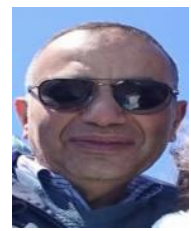

\section{Hatem H. Ghith}

B.Sc. Civil Engineering Department, Cairo University Egypt.

M.Sc. Helwan University, Egypt

Ph.D. Helwan University, Egypt.

Research Fields: Reinforced Concrete - Repairs of Concrete Structures. 